\title{
Respiratory electron transport system (ETS) activities in zooplankton and micronekton of the Indo-Pacific region
}

\author{
P. H. Schalk \\ Netherlands Institute for Sea Research, PO Box 59, 1790 AB Den Burg, Texel, The Netherlands
}

\begin{abstract}
ETS activities of natural zooplankton assemblages and some micronekton species from the eastern Banda Sea and western Arafura Sea (Indonesia) were measured during the SE and NW monsoons, when respectively rich upwelling and poor downwelling conditions occur. Weight-specific ETS activities of the zooplankton community decreased with depth; 13 to $20 \%$ of this decrease was related to temperature, and another 5 to $10 \%$ to higher water contents of the deeper samples. Large geographical differences, but no seasonal differences, were detected within the area studied. About $65 \%$ of the total zooplankton ETS activity in the upper $500 \mathrm{~m}$ was confined to the upper $100 \mathrm{~m}$. Day' night differences in ETS profiles were observed during the less fertile NW monsoon period, attributed to diel vertical migration of the zooplankton, and resulting in a 9 to $36 \%$ lower activity in the water column during daytime. Since no diel migration by the zooplankton was seen in the fertile SE monsoon season, the abundance of food, or the necessity to conserve energy, seems a major factor in determining diel vertical migration. Of the micronekton examined, shallow-living species and those performing diel vertical migration showed higher weight-specific ETS activities than deeper living and non-migrating species. Myctophid fishes and carid crustaceans showed very high weight-specific activities; chauliodontids, gonostomatids, euphausids and sergestids moderate activities; and leptocephali, chatognaths, saips, siphonophores and medusas low activities. None of the micronekton species investigated showed seasonal differences in ETS activity.
\end{abstract}

\section{INTRODUCTION}

Various factors, such as temperature, salinity, sexual stage and food abundance, influence the respiratory activity of zooplankton (see Raymont 1983 for review). Differences in respiratory activity of organisms observed between tropical and arctic regions (Ikeda \& Hing Fay 1981) and shallow and deeper strata (Torres et al. 1979) are apparently primarily related to temperature, but adaptations to environmental conditions are possible (Anraku 1964, Musayeva \& Shushkina 1978, Båmstedt 1980, Hirche 1984). Small-scale geographical differences were also observed in zooplankton species (Marshall 1973). Seasonal differences in respiratory rate of zooplankton have been reported by Marshall \& Orr (1956), Conover (1959), Conover \& Corner (1968), Gaudy (1973) and Raymont (1983).

Changes in respiratory activity are closely associated with changes in the basic respiratory enzymes (Ikeda \& Skjoldal 1980) and can therefore be monitored by measurements of the respiratory electron transport system (ETS) activity (Packard 1971). Starvation experiments with marine organisms showed a decrease in both respiratory and ETS activities (Finlay et al. 1983), with a time lag of 1 to $3 \mathrm{~d}$ between the two for zooplankton (Bămstedt 1980). Respiration experiments with open ocean zooplankton are subject to large errors as a result of capture stress and constraints in the experimental set up (Skjoldal \& Båmstedt 1977, Raymont 1983). Measuring the ETS activity in (marine) organisms provides a representative, although relative, indication of the respiratory activity (Båmstedt 1979), and has been used for bacteria (Christensen \& Packard 1979, Christensen et al. 1980), phytoplankton (Packard 1971, Kenner \& Ahmed 1975a, b, Vosjan \& Nieuwland 1987 ) and zooplankton (King \& Packard 1975, Owens \& King 1975, Båmstedt 1979, 1980, Bigidaire et al. 1982).

The 'Snellius II' cruises (Schalk 1987, Baars \& Zijlstra 1988) offered an opportunity to investigate spatial and seasonal variability in the ETS activity of zooplankton 
and micronekton, as well as its distribution with depth and possible diurnal rhythms. The Indo-Pacific waters, especially the Banda Sea region, are strongly influenced by alternating monsoon winds. During the SE monsoon (May to September) fertile upwelling conditions occur in this area, while during the NW monsoon (November to April) oligotrophic downwelling conditions predominate (Wyrtki 1957, 1961, Baars \& Zijlstra 1988, Zijlstra et al. 1988). The seasonal variations in hydrography and fertility are likely to be responsible for observed fluctuations in biomass, vertical distribution and diel migration activity of the zooplankton (Schalk 1987). Considering the impact of the monsooninduced environmental changes on the horizontal and vertical distribution of the zooplankton, changes in biological respiratory activity, and therefore in ETSactivity, could also be expected.

\section{MATERIAL AND METHODS}

During the Indonesian-Dutch 'Snellius II' expedition (May 1984 to July 1985) 2 identical cruises (August 1984, SE monsoon, and February 1985, NW monsoon) were carried out in the eastern Banda Sea and western Arafura Sea. During each cruise (Fig, 1) the upper $300 \mathrm{~m}$ of the water column was sampled at 12 'survey' stations in strata of 0 to 100 and 100 to $300 \mathrm{~m}$ at night. In addition, at 4 'drogue' stations, in the vicinity of a radio-drogue-buoy, both night and day samples were taken in discrete layers of $100 \mathrm{~m}$ from 0 to $500 \mathrm{~m}$ (for a detailed description see Schalk 1987).
The sampler used was a RMT 1+8 (Baker et al. 1973), which is an opening and closing trawl net system with 2 different nets: the RMT1 with a mesh-size of $320 \mu \mathrm{m}$ and the RMT8 with a mesh-size of $4.5 \mathrm{~mm}$. The opening and closing of the nets is acoustically controlled. The speed indicator on the net provides a measure of distance sampled. Roe et al. (1980) described the relation between net speed and mouth angle so that the volume of water filtered can be estimated.

Subsamples of the RMT1 catches at the drogue stations (3) of the August cruise and at both survey (12) and drogue stations (3) of the February cruise were used to determine the ETS activity of the 'natural' zooplankton assemblage, as sampled with the net. Some micronekton species from the RMT8 catches of both cruises were also processed. Zooplankton biomass was determined by measuring the displacement volumes of the catch (Schalk 1987). After the displacement volume was measured the sample was stirred and filtered on a $320 \mu \mathrm{m}$ mesh sieve. Organisms larger than $5 \mathrm{~mm}$ (mainly jellies) were removed (cf. Bigidaire et al. 1982), because larger organisms and/or jellies would disproportionally influence the small amount of catch taken out for ETS experiments. The subsamples were stored in a refrigerator at $1{ }^{\circ} \mathrm{C}$ for a maximum of $12 \mathrm{~h}$ before processing

The ETS activity of the zooplankton was measured according to the method originally described by Packard (1971) and modified by Owens \& King (1975). A $1 \mathrm{ml}$ subsample of the catch was homogenized in $20 \mathrm{ml}$ ETS-B (Owens \& King 1975) with an Ultraturrax tissue homogenizer at maximum speed $(20000 \mathrm{rpm})$ for

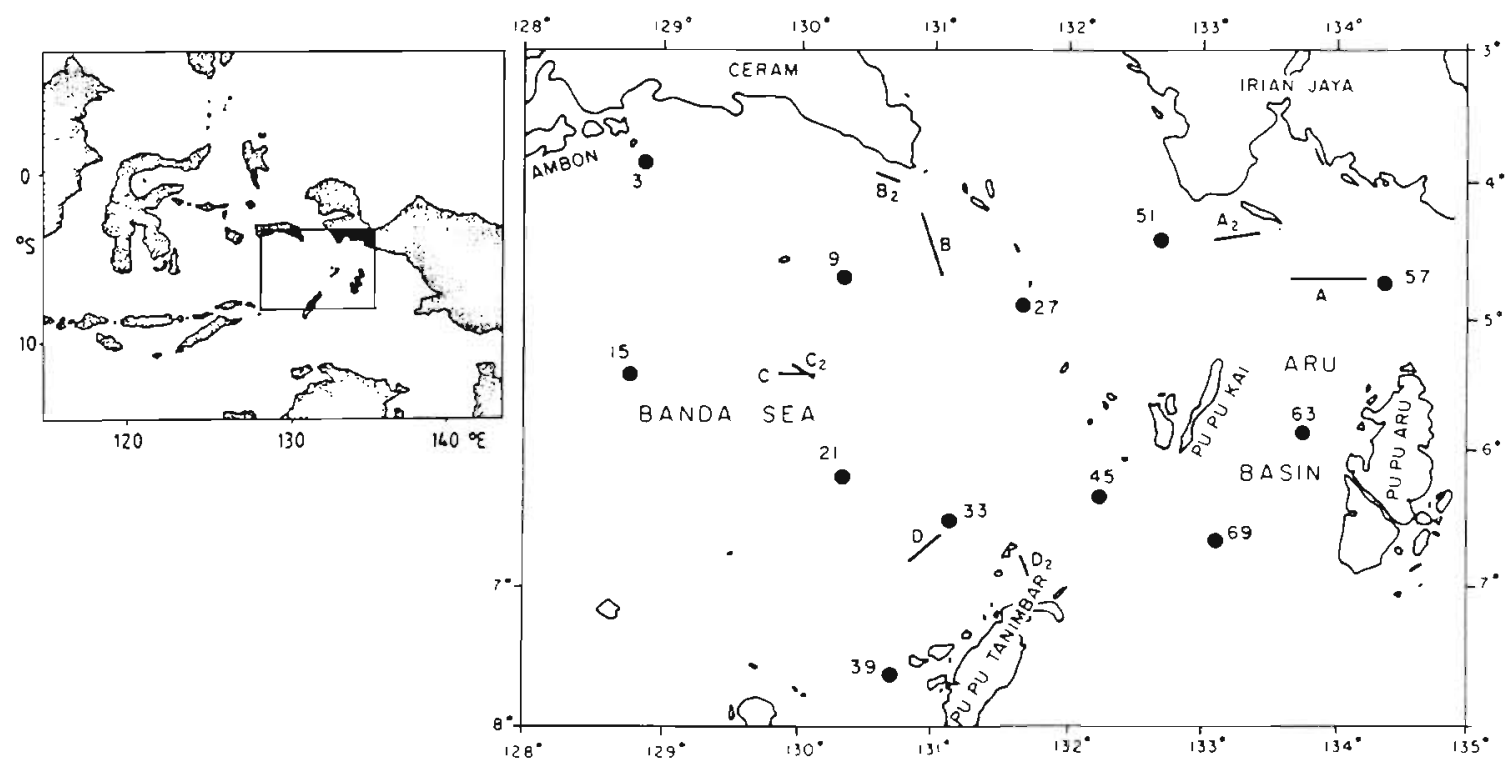

Fig. 1. Eastern Banda Sea and western Arafura Sea with the location of the 12 survey stations 'dots) and 4 drogue stations (lines) $A, B, C, D$ for the August cruise, $A_{2}, B_{2}, C_{2}, D_{2}$ for the February cruise 
1 min. Care was taken not to overheat the homogenate. Larger micronekton organisms were cut into small pieces before homogenizing. From 1 to 5 animals were used per experiment. Centrifugation was omitted (Finlay et al. 1983) because this does not improve the measured activity and the omission saves time. The homogenate was left for $10 \mathrm{~min}$ to let larger particles (pieces of scales, spines) settle, then $1 \mathrm{ml}$ was pipetted out of the upper part and diluted to obtain a concentration of 1 to $5 \mu l$ sample per $\mathrm{ml}$ of homogenate (Owens \& King 1975). Reactions were performed for $40 \mathrm{~min}$ at $25^{\circ} \mathrm{C}$, which is close to the average temperature in the upper $100 \mathrm{~m}$ of the water column. Absorption was measured with a Pye Unicam photometer at $490 \mathrm{~nm}$, directly after the reaction was stopped, as termination by the quench solution may not be complete (Finlay et al. 1983). Values were corrected for a reagent and turbidity blank. A temperature calibration in the range of 10 to $29^{\circ} \mathrm{C}$, corresponding to depths from $500 \mathrm{~m}$ to surface, for the ETS reactions of the zooplankton samples was obtained, in order to calculate in situ activities.

After the cruises the dry weights of the preserved zooplankton samples (either in $70 \%$ alcohol or $4 \%$ formalin were determined, by drying to constant weight for $3 \mathrm{~d}$ at $60^{\circ} \mathrm{C}$ in a well-ventilated oven, at the home laboratory (Beukema 1974), as depth-dependent differences may be present (Torres et al. 1979).

The method of homogenization used and the influence of short-term storing of the ETS samples at $1{ }^{\circ} \mathrm{C}$ were tested at the home laboratory with some North Sea zooplankion species.

\section{RESULTS}

Samples subjected to a second step of homogenizing as teflon glass grinding (Owens \& King 1975), sonification (Finlay et al. 1983) or both did not show significantly higher ETS activities than those treated solely with the Ultraturrax (Table 1). Centrifugation was found to be unnecessary, except in the case of teflon glass grinding, where probably the very turbid homogenates resulted in lower measured activities.

Samples for ETS experiments stored in a refrigerator at $1{ }^{\circ} \mathrm{C}$ could be kept without loss of activity for at least $15 \mathrm{~h}$, but after this period a large variation in the activity of the various samples was observed (Fig. 2). This applied to both whole organisms and their homogenates. Some homogenates showed an increase in activity during the first hours of storage, possibly due to an incomplete extraction of enzymes directly after homogenization. Possibly, remaining enzymes, accounting for up to $15 \%$ of the maximum activity, were liberated during the first hour of storage by autolysis of unhomogenized cells.
Table 1. Effectivity of the homogenizing method on the measured weight-specific ETS activity (as percentage of the highest measured value) tested on 2 samples of 10 specimens each of the North Sea shrimp Crangon crangon. H: homogenization with the Ultraturrax, followed by $\mathrm{T}$ : teflon glass grinding; U: sonification; $\mathrm{C}$ : centrifugation. AP: activity in the pellet of centrifuged homogenate of experiment HC

\begin{tabular}{|lc|}
\hline Method & Relative ETS $(\%)$ \\
\hline H & $97.6 \pm 5.2$ \\
HC & $98.7 \pm 6.7$ \\
HT & $87.3 \pm 0.2$ \\
HTC & $99.8 \pm 0.7$ \\
HTU & 100.0 \\
HTUC & $100.0 \pm 0.2$ \\
HU & $96.4 \pm 2.1$ \\
HUC & $99.4 \pm 0.4$ \\
AP & 4.0 \\
\hline
\end{tabular}

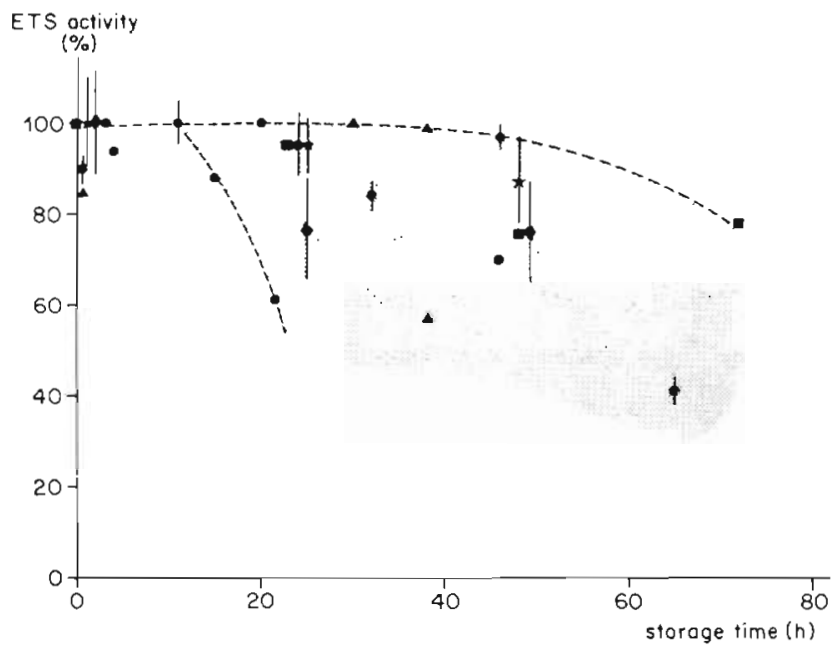

Fig. 2. Deterioration in ETS activity (highest measured values set to $100 \%$ ) with storage time at $1^{\circ} \mathrm{C}$ in a refrigerator for whole animals: $(\bullet)$ Pomatoschistus lozanoi, (₫) Beroe cucumis,

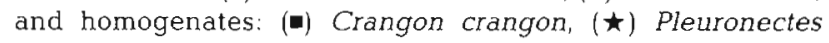
platessa, (•) Solea solea

The relation between ETS activity of the Banda Sea zooplankton and temperature (Fig. 3) was found to be approximately linear (Finlay et al. 1983) in the temperature range of the sampled strata, and deviates from the Arrhenius equation given by Owens \& King (1975). As the ETS activities of the zooplankton samples collected in the Banda Sea area were all measured at $25^{\circ} \mathrm{C}$, values for the deeper strata have been corrected to in situ temperature according to this relation.

The weight-specific ETS activity (WSA, in $\mu$ g-at $O$ [g wet $w \mathrm{t}]^{-1} \mathrm{~h}^{-1}$ ) of the Banda Sea zooplankton measured at $25{ }^{\circ} \mathrm{C}$ decreased with increasing depth of the samples and after correction to in situ temperature this becomes even more apparent (Fig. 4). Temperature accounted for 13 to $20 \%$ of the decrease in WSA with 


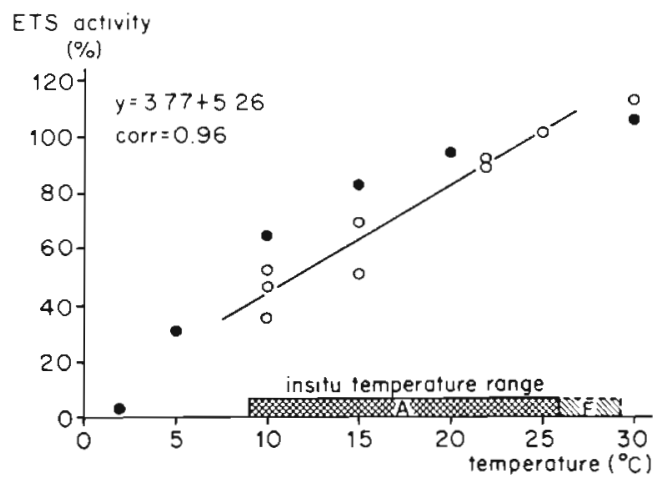

Fig. 3. Relation between weight-specific ETS activity of Banda Sea zooplankton samples and temperature $\left({ }^{\circ} \mathrm{C}\right)$, calculated according to $(\bullet)$ the Arrhenius equation (Owens \& King 1975) and $(0)$ own calibration (ETS $=3.77$ temp. $+5.26, r=0.96$ ) ETS activities are expressed in percentages relative to the value at $25^{\circ} \mathrm{C}$, the average temperature in the upper layer

depth relative to the upper layer value. The proportional dry weights (DW) were significantly lower for the alcohol-preserved samples (DW $=7.11 \pm 0.93 \%$ of the weight) than for the formalin-preserved samples (DW $=10.01 \pm 0.66$ ) where the latter was in close agreement with the ratio obtained from fresh North Sea material. Hence, for comparison the alcohol figures have been corrected to formalin figures using the average ratios between them. The dry weights of the zooplankton samples were found to range from 7 to $12 \%$ of the wet weights, and showed a significant decrease with depth (Fig. 4). As the WSA is expressed per unit of wet weight this accounts for a further 5 to $10 \%$ of the decrease in WSA with depth in the zooplankton samples.
The total ETS activity in the water column attributed to zooplankton ( $\mathrm{TA}$, in $\mu \mathrm{g}$-at $\mathrm{O} \mathrm{m}^{-3} \mathrm{~h}^{-1}$ ) was calculated by multiplying the weight-specific activities of the zooplankton samples by the biomass of these samples in the discrete depth layers as given by Schalk (1987). When considering the upper $500 \mathrm{~m}$ stratum no differences in biomass between day and night were present (Fig. 5), suggesting no enhanced net avoidance during daytime and no significant migration of the population out of the depth range sampled. The TA also decreased with depth, and day/night differences were present. From night to day TA decreased in the 0 to $100 \mathrm{~m}$ layer and increased in the deeper layers (Fig. 5). The 3 stations ( $A, B$ and C) of the February cruise, of which complete day and night series of discrete depth samples were available, show that the total ETS activity of the zooplankton in the water column (0 to $500 \mathrm{~m}$ ) was 9 to $36 \%$ lower during the day than during the night.

As a result of the local differences in WSA and biomass of the zooplankton samples studied, the ETS activity in the water column attributed to zooplankton (TA) showed considerable geographical differences in the area studied (Fig. 6). Highest TA values were encountered in the southeastern part, gradually decreasing towards the northwest. The spatial distribution of the ETS activities did not show the same pattern as the biomass, but in both cases the highest values were found in the eastern part of the area. For the August cruise only ETS data of 3 drogue stations were available, which also indicated local differences.

ETS activities of zooplankton catches on the drogue stations of the August and February cruises were compared (Table 2). In August the WSA of the zooplankton caught in the upper layer (0 to $100 \mathrm{~m}$ ) varied from 20 to

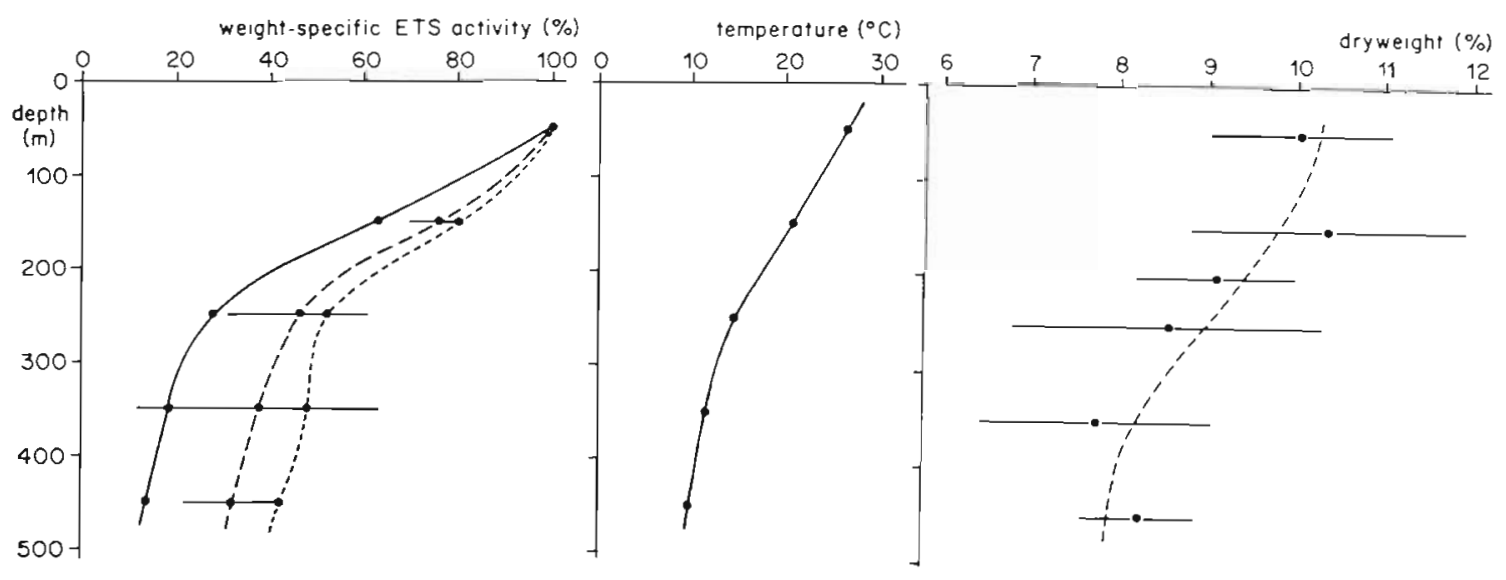

Fig. 4. Left: Vertical distribution of weight-specific ETS activity (deeper layers as percentage of 0 to $100 \mathrm{~m}$ layer value) of zooplankton based on night samples of February drogue stations. (-): ETS activities corrected to in situ temperature; (--) measured activities (mean and standard deviations) at $25^{\circ} \mathrm{C} ;(--)$ measured activities corrected for differences in water contents of the samples. Middle: Average temperature profile for the 4 drogue stations in February. Right: Dry weights in percentage of wet weight (mean and standard deviations) of the Banda Sea zooplankton in the various discrete depth layers sampled for the February drogue stations. Line fitted by eye 

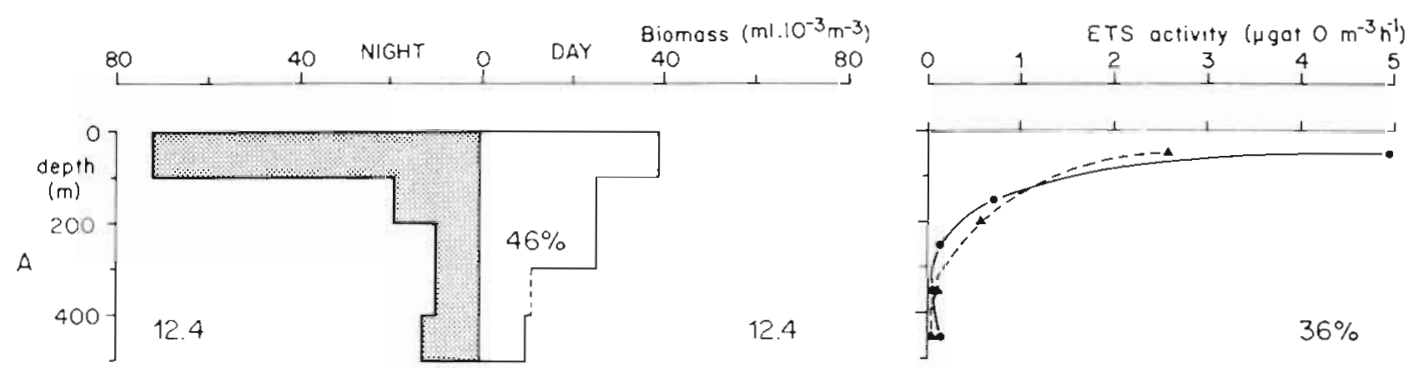

12.4
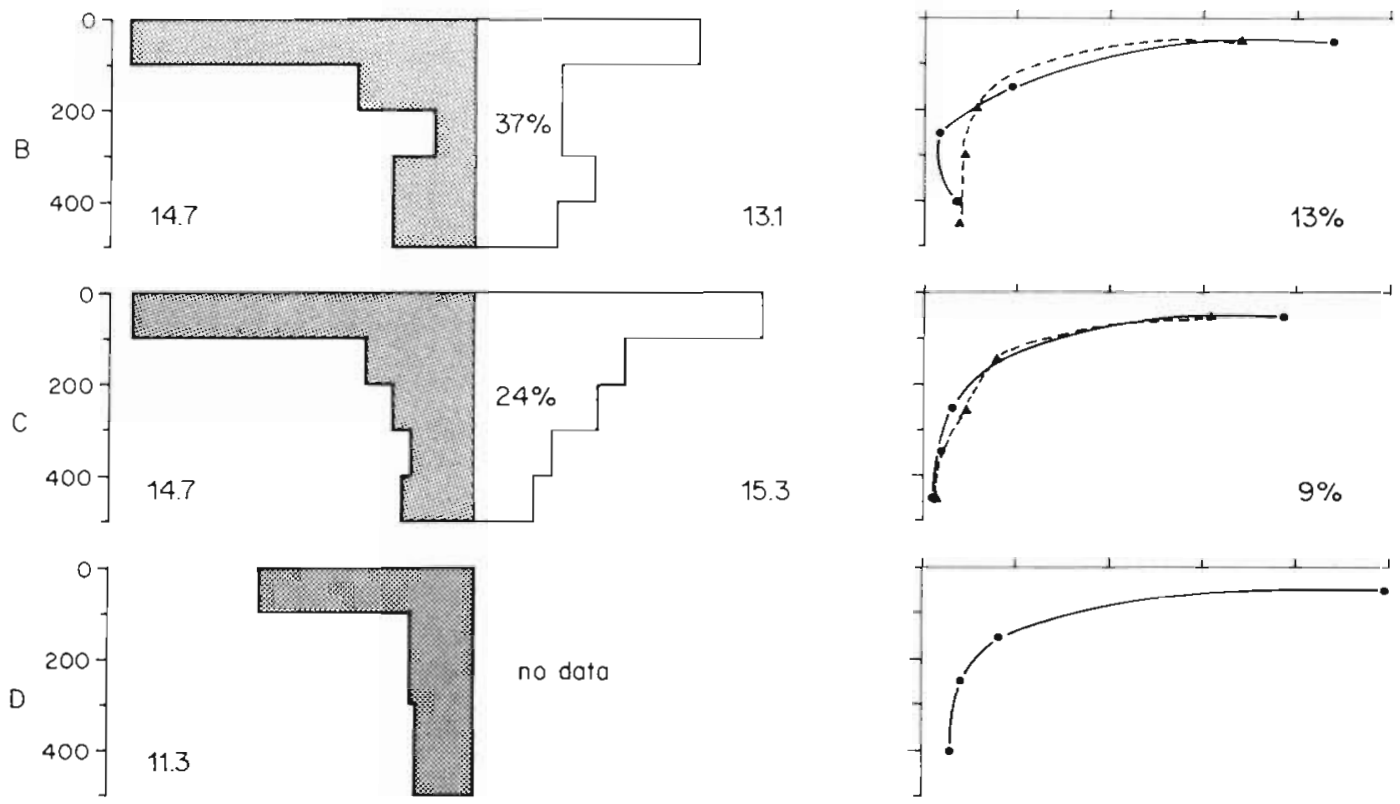

no data

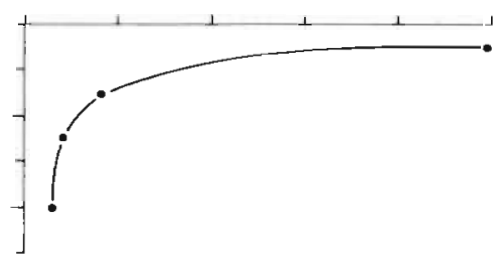

Fig. 5. Lefi: Vertical distribution of zoopiankton biomass at night and day in the discrete depth layers sampled at the February drogue stations. Numbers left and right indicate the total amount of zooplankton (in $\mathrm{ml} \mathrm{m}^{-2}$ ) in the water column for night and day respectively. Percentages indicate the relative amount of biomass migrating between the depth layers sampled (after Schalk 1987). Right: Profiles of ETS activity, attributed to zooplankton in the water column for (-) night and (--) day. Percentages indicate difference between total night and day activities, the latter being lower

$82 \mu \mathrm{g}$-at $\mathrm{O}(\mathrm{g} \text { wet } w \mathrm{t})^{-1} \mathrm{~h}^{-1}$, while in February they ranged from 48 to 114 . With the relatively high variance in WSA values between stations no significant difference between the 2 cruises was apparent. When the activity of the zooplankton is expressed per unit of seawater filtered (TA) the average total activity of the zooplankton in the upper $300 \mathrm{~m}$ was about twice as high in August as in February, reflecting the seasonal difference between the zooplankton biomasses, which were on average 20.0 and $9.5 \mathrm{ml} \mathrm{m}^{-2}$ respectively (Schalk 1987).

The ETS activities of some micronektonic species were determined (112 experiments) showing large differences (within species) among stations as well as among taxa investigated (Fig. 7). In general very low activities were measured for leptocephali, chaetognaths, tunicates, siphonophores and medusas, ranging from 1 to $20 \mu \mathrm{g}$-at $\mathrm{O}$ (g wet $\mathrm{wt})^{-1} \mathrm{~h}^{-1}$. Gonostomatids, sternoptychids, chauliodontids, stomatids, euphausids, sergestids and copepods showed moderate activities varying from 20 to $150 \mu \mathrm{g}$-at $\mathrm{O}(\mathrm{g} \text { wet } \mathrm{wt})^{-1} \mathrm{~h}^{-1}$. Very high activities, between 120 and $410 \mu \mathrm{g}$-at $\mathrm{O}$ (g wet $\mathrm{wt})^{-1} \mathrm{~h}^{-1}$, were found in the mycotophids, percichtids and carids. No seasonal differences in WSA of the micronektonts investigated were observed.

\section{DISCUSSION}

The method applied for homogenization proved to be quick and renders ETS values which do not differ from other methods. Leaving out the centrifugation step as described by Finlay et al. (1983) for protozoans is also applicable to zooplankton and micronekton.

The literature on preservation of ETS samples shows some contradictory results. Present data indicate that storing the samples, whole organisms or their homogenates for up to $15 \mathrm{~h}$ at $1^{\circ} \mathrm{C}$ causes no loss in 


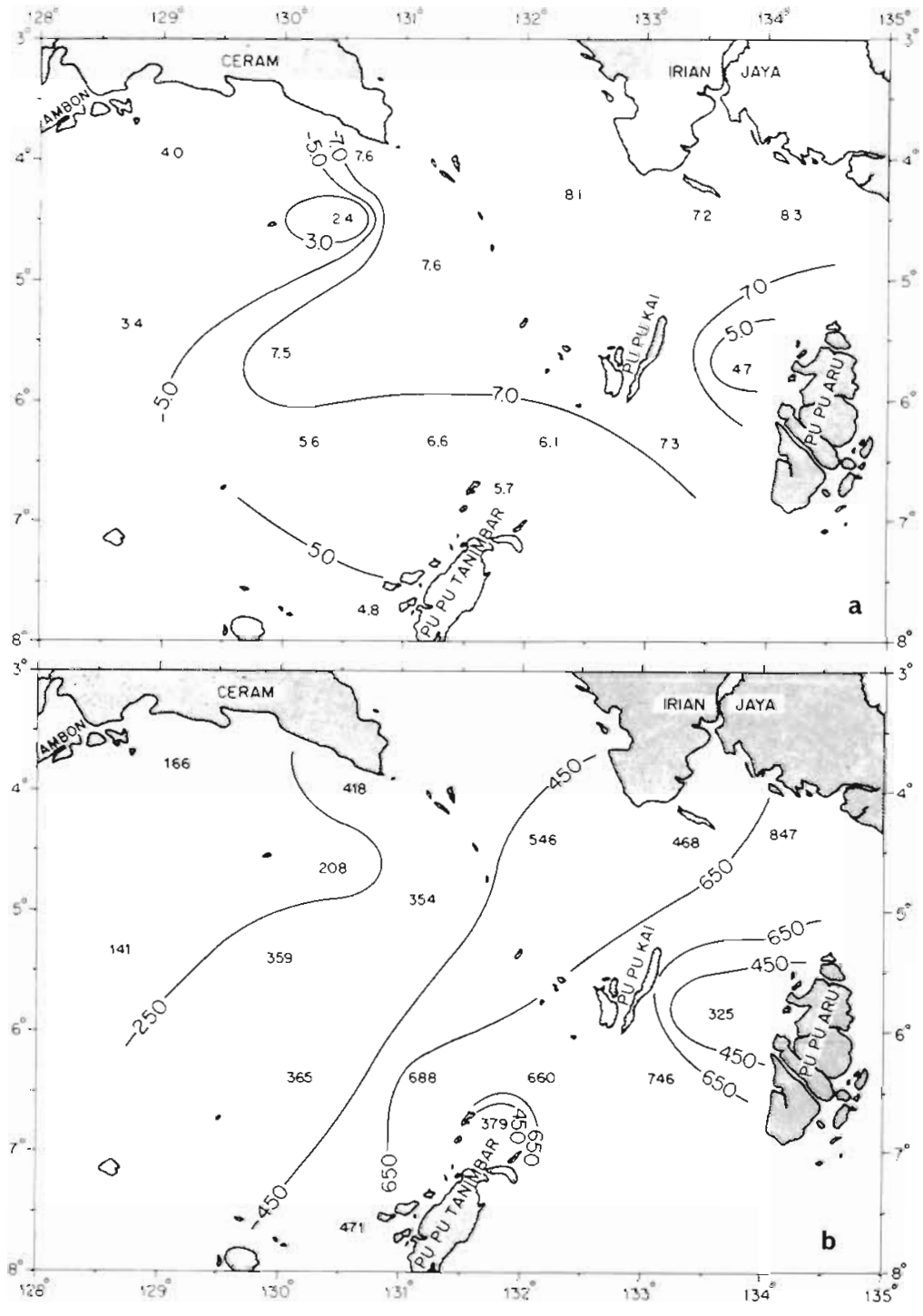

Fig. 6. Geographical distribution of (a) zooplankton biomass $\left(\mathrm{ml} \mathrm{m}^{-2}\right)$ in the upper $100 \mathrm{~m}$ and (b) ETS activity in the water column attributed to zooplankton $\left(\mu \mathrm{g}\right.$-at $\left.\mathrm{O} \mathrm{m}^{-2} \mathrm{~h}^{-1}\right)$ in the upper $100 \mathrm{~m}$ for the February cruise activity. This is in contrast to the findings of some authors reporting a more or less rapid inactivation in homogenates, e.g. a loss of $50 \%$ in activity after 4 h at

Table 2. Comparison of average ETS activities of zooplankton night catches at drogue stations in the upper $300 \mathrm{~m}$ between the August and February cruises. WSA: weight-specific activity, in $\mu \mathrm{g}$-at $\mathrm{O}$ (g wet $\mathrm{wt})^{-1} \mathrm{~h}^{-1}$; TA: activity in the water column attributed to zooplankton, in $\mu \mathrm{g}$-at $\mathrm{O} \mathrm{m}^{-3} \mathrm{~h}^{-1}$. Total activity in the 0 to $300 \mathrm{~m}$ layer is given in $\mu \mathrm{g}$-at $\mathrm{O} \mathrm{m}^{-2} \mathrm{~h}^{-1}$

\begin{tabular}{|lccccc|}
\hline $\begin{array}{l}\text { Stratum } \\
\text { (m) }\end{array}$ & \multicolumn{2}{c}{ WSA } & Feb & Aug & Feb \\
\hline $0-100$ & $51.1 \pm 31.7$ & $63.2 \pm 14.2$ & $6.9 \pm 4.9$ & $4.1 \pm 0.5$ \\
$100-200$ & $30.6 \pm 25.1$ & $44.2 \pm 12.4$ & $1.5 \pm 0.6$ & $0.9 \pm 0.1$ \\
$200-300$ & $28.3 \pm 17.5$ & $23.2 \pm 10.1$ & $0.8 \pm 0.5$ & $0.3 \pm 0.2$ \\
$0-300$ & & & $920 \pm 5.8$ & $530 \pm 0.8$ \\
\hline
\end{tabular}

$0{ }^{\circ} \mathrm{C}$ in protozoans (Finlay et al. 1983) and after $30 \mathrm{~h}$ at $2{ }^{\circ} \mathrm{C}$ in copepods (Båmstedt 1980). For homogenates kept at room temperature even a decrease of $97 \%$ of activity after $3 \mathrm{~h}$ is reported by Båmstedt (1980). Such a sensitivity was not found in the present experiments with North Sea and Banda Sea zooplankton. A forgotten RMT1 sample (unhomogenized) left on the bench for several hours at $25^{\circ} \mathrm{C}$ did not show any loss in activity compared to other immediately cooled samples. Similar differences are reported for long-term storing. Ahmed et al. (1976), Ikeda \& Skjoldal (1980) and Ikeda \& Hing Fay (1981) apparently recorded good results with freezing and storing their samples lof whole organisms) at $-20^{\circ} \mathrm{C}$, but others (with homogenized samples) did not (Packard 1971, Båmstedt 1980). Apparently many factors influence the ETS activity in the samples. Possibly the method of homogenization affects the tenability of the 


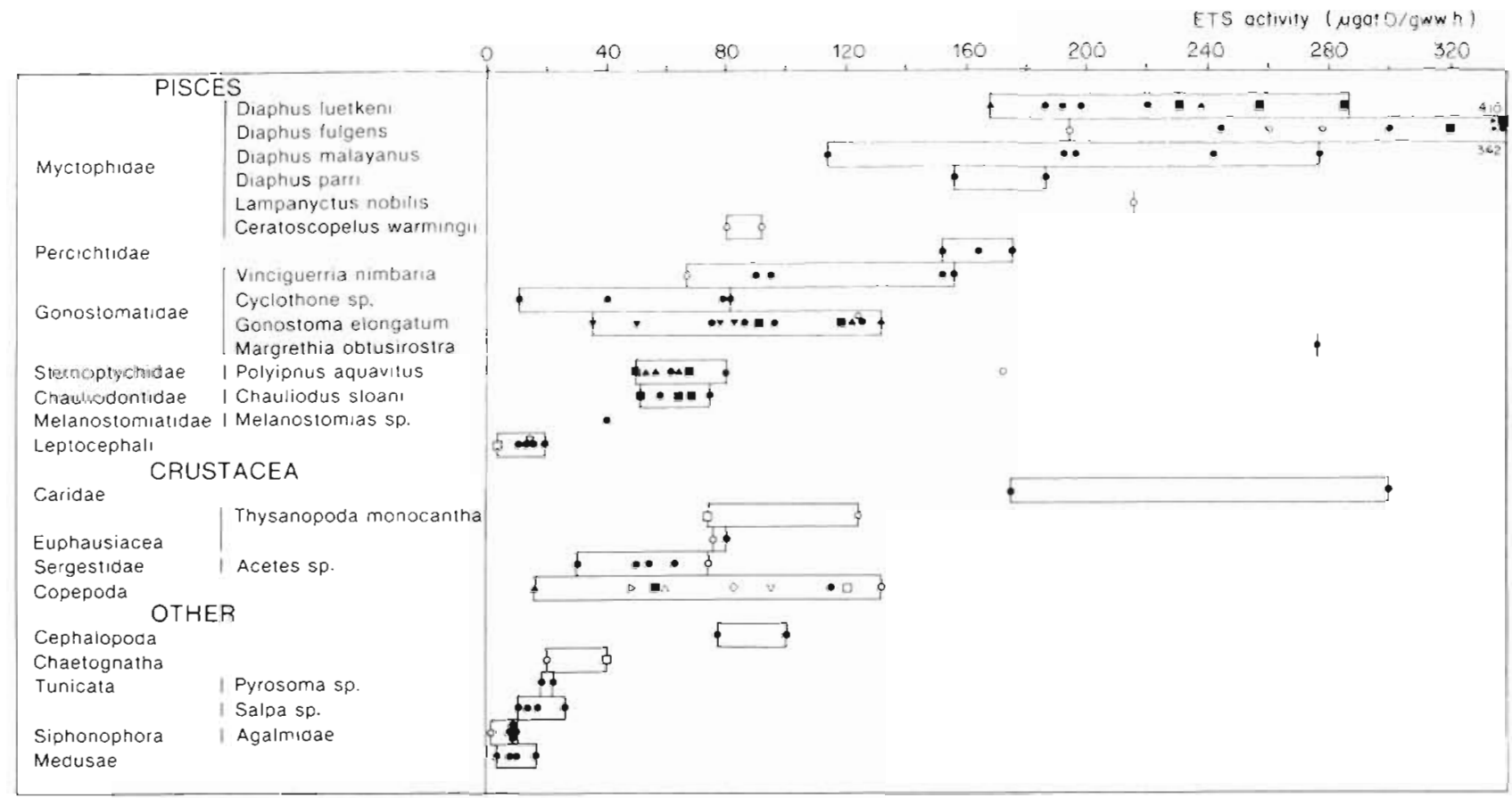

Fig. 7. Weight-specific ETS activities ( $\mu$ g-at $O$ [g wet $w t]^{-1} \mathrm{~h}^{-1}$ ) in the planktonic groups studied. Different symbols represent measurements at different stations, bars indicate the range in activity. Closed symbols: August cruise; open symbols: February cruise

homogenates, since all reports on deteriorating homogenates concerned samples homogenized by teflon glass grinding. Present data show that samples for ETS measurements can be stored for a short period, but in view of the doubtful results with prepared homogenates, storage can best be done with whole organisms.

The Banda Sea data show that the ETS activity per unit of zooplankton biomass (WSA) decreases rapidly with increasing depth in the night samples. Of this decrease, 13 to $20 \%$ was the result of the lower temperatures in the deeper strata, and another 5 to $10 \%$ was attributed to a higher water content of the deeper zooplankton samples (Fig. 4). Torres et al. (1979) found a similar trend comparing shallow and deep-living midwater fishes, although in their case only $2 \%$ of the decreasing respiratory rate with depth was accounted for by temperature and $30 \%$ by higher water contents of the deeper-living species. The remaining unexplained 70 to $80 \%$ of the decrease in ETS activity with depth in the present samples agrees with the findings of Torres et al., who suggested that lower respiratory rates are characteristic of deeper-living species. Declining metabolic rates with increasing depth of occurrence appears to be a general characteristic for pelagic organisms (Packard et al. 1975, Jannasch \& Wirsen 1973, Jannasch et al. 1976, Childress 1969, 1971, 1975, Torres et al. 1979). However, Devol (1981) and Bigidaire et al. (1982) found no consistent pattern in ETS activities of zooplankton with depth, although Devol often found the bulk of the respiration at the oxycline.

The zooplankton ETS activity per $\mathrm{m}^{3}$ of filtered seawater showed differences between day and night profiles presumably as a result of the day/night differences in biomass in the discrete depth layers sampled caused by diel migration (Fig. 5). During the day a decrease in activity in the shallow layers was measured and a small increase in deeper layers. Due to the lower temperatures in the deeper strata the total ETS activity (TA) of the zooplankton in the upper $500 \mathrm{~m}$ is lower during day than during night and diel vertical migration of the zooplankton community resulted in a saving of 9 to $36 \%$ in ETS activity for the stations studied (Fig. 5). Obviously the amount of this decrease is related to the migratory activity (depth of migration and amount of biomass migrating) of the zooplankton. In this context it is interesting to note that diel migratory activity in zooplankton was clearly present in the poorer downwelling season, but not in the fertile upwelling period (Schalk 1987). Seasonal differences in migratory behaviour were also found by Roe (1984) in the North Atlantic Ocean. The fact that migration to deeper and colder layers during the day might be important for conserving energy of the zooplankters has been discussed before (e.g. McLaren 1963, Teal \& Carey 1967. Smith \& Teal 1973, Huntley \& Brooks 1982, Angel 1986), but the present data allow a quantification under 
field conditions. Furthermore, the data suggest that apart from the obvious factors of light and temperature, abundance of food, or the necessity to conserve energy, plays an important role in determining migratory activity of the zooplankton population.

The WSA in the zooplankton samples determined at 16 stations in February indicated large spatial differences on a relatively small geographical scale, and although less data ( 3 stations) were available for the August cruise, a similar variability seemed present. Also for the studied micronekton species the WSA showed considerable differences (up to a factor of 4 ) between the stations in both seasons. This confirms earlier observations on geographical differences in respiratory activity in populations of copepods (Conover 1959, Omori 1970, Ikeda 1970). Finlay et al. (1983) found that differences in WSA of protozoan samples were associated with different growth rates. High and low WSA values of the zooplankton samples studied may indicate growing or declining populations, or the beginning or end of a bloom. The relations of respiratory activity with growth (Marshall \& Orr 1956, Mullin \& Brooks 1970, Marshall 1973), reproduction (Finlay et al. 1983), but also crowding (Razouls 1972, Marshall 1973) and starvation (Ikeda \& Skjoldal 1980) have been demonstrated many times. From the above it may be clear not only that the biomass of the zooplankton or the micronekton compartment determines the impact upon the pelagic ecosystem but that metabolic activities have also to be taken into account. Fig. 6 clearly demonstrates the difference in distributions of zooplankton biomass and that of ETS activity attributed to zooplankton in the area studied.

Large differences in WSA were found for the various micronekton groups investigated (Fig. 7). Very low activities were measured for leptocephali, chaetognaths, salps, siphonophores and medusas, all organisms with relatively high water contents. However this does not necessarily mean that these groups are of lesser importance to the pelagic ecosystem (Biggs 1977 , Alldredge 1984). Salps and siphonophores can occur in enormous numbers during bloom periods (Wiebe et al. 1979). In the August samples from the Banda Sea area the fraction of gelatinous plankton amounted to $40 \%$ of the total weight of the RMT8 catches at several stations (Schalk \& Witte unpubl.). Of the investigated fishes, shallow-living (Percichtidae) and diel-migrating (Diaphus spp.) species showed relatively high activities, while deeper-living (i. e. Gonostoma elongatum, Chauliodus sloani) and non-migrating species (Cyclothone sp., Polyipnus aquaviti) showed lower activities. This is in agreement with the studies of Childress $(1971,1975)$ who reported respiratory rate to be dependent on the depth of occurrence, and Torres et al. (1979) who reported higher respiratory rates in migrating midwater fishes compared to non-migrating species, Of the crustaceans, the Caridae - active diel migrators - showed high activities comparable to the myctophid fishes, but both euphausids and sergestids, which also exhibit diel migration, showed moderate activities comparable with deeper-living fishes.

Considering the strongly varying environmental factors between the 2 cruises in the area studied (Baars \& Zijlstra 1988), and the known influences of growth, reproduction, crowding and starvation on the respiratory activity, it was expected that there would be seasonal changes in weight-specific ETS activities of the zooplankton and micronekton. However, a comparison between the ETS data of the 2 cruises did not show a difference in the WSA of the zooplankton samples (Table 3) nor in the investigated micronekton species in these waters (Fig. 7).

The fact that the TA for zooplankton is about twice as high during the SE monsoon with upwelling, than during the NW monsoon with less fertile conditions, is a result of the difference in biomass between the seasons (Schalk 1987). If the ETS activities measured at the drogue stations in August are representative for the whole area, as is the case in February, than it may be concluded that the response of the zooplankton/micronekton community to the seasonal changes in hydrography and fertility in the area is reflected mainly by variance in biomass and behaviour (migration) and not by an adjustment in specific activity. This agrees with the results of Finlay et al. (1983) who found that protozoans changed in cell size but not in specific activity under changing environmental conditions. Although marine organisms are apparently capable of

Table 3. Average stocks (in $\mathrm{g} \mathrm{C} \mathrm{m}^{-2}$ ) and flows (in $\mathrm{g} \mathrm{C} \mathrm{m}^{-2} \mathrm{~d}^{-1}$ ) of some compartments of the pelagic ecosystem of the Banda Sea area as measured in August 1984 and February 1985. For phytoplankton the stock was calculated from chlorophyll a concentration, using the average C/chl a ratio of 102 given by the author; the flow was measured as primary production

\begin{tabular}{|lccccc|}
\hline \multirow{2}{*}{ Compartment } & \multicolumn{2}{c}{ Stocks } & \multicolumn{2}{c|}{ Flows } & Source \\
& Aug & Feb & Aug & Feb & \\
\hline Chlorophyll a & 3.7 & 2.1 & 1.9 & 0.9 & Gieskes et al. 1988 \\
Zooplankton, RMT1 & 1.0 & 0.5 & 0.063 & 0.037 & Present study \\
Micronekton, RMT8 & 0.2 & 0.1 & 0.018 & 0.009 & Present study \\
\hline
\end{tabular}


changing their respiratory enzyme activity under all kinds of stress under laboratory conditions, it is a feature that was not found under field conditions, which change considerably with the seasons in the area studied.

ETS/respiration ( $\mathrm{R}$ ) ratios of 2.6 have been reported for natural zooplankton assemblages (Bigidaire et al. 1982) and species-specific ratios vary from 1.9 for euphausids (Ikeda \& Hing-Fay 1981), 2.02 for copepods (Oosterhuis pers comm.), and 2.3 for Crangon species (Bouwmeester unpubl.), to between 3.4 and 6.3 for Acetes species (Ikeda \& Skjoldal 1980) and 6.2 for Pomatoschistus species (Schalk unpubl). Calculation of respiratory activities from the present ETS values using the conversion factors mentioned above come well into the range of observations on tropical zooplankton: i. e. 40 to $73 \mu \mathrm{g}$-at $\mathrm{O}$ (g wet $\mathrm{wt})^{-1} \mathrm{~h}^{-1}$ for copepods (Ikeda 1974), 28 to $38 \mu \mathrm{g}$-at $\mathrm{O}$ (g wet $w \mathrm{t})^{-1} \mathrm{~h}^{-1}$ for euphausids (Ikeda 1974); 23 to $34 \mu \mathrm{g}$-at $\mathrm{O}$ (g wet wt) $\mathrm{h}^{-1}$ for Acetes species (Ikeda \& Skjoldal 1980), and 7 to $12 \mu \mathrm{g}$-at O ( $\mathrm{g}$ wet $w t)^{-1} h^{-1}$ for siphonophores (Biggs 1977).

For an impression of the role of zooplankton and micronekton in the carbon flow in the pelagic system, the ETS values were recalculated to carbon units, because such units are often used in ecological studies and make comparison easier. Based upon the mean ETS figures (Table 2) and assuming an ETS/R ratio of 2.6 (Bigidaire et al. 1982) and a respiratory quotient of 0.8 , the average carbon requirement of the zooplankton community in the Banda Sea area would be approximately $0.063 \mathrm{~g} \mathrm{C} \mathrm{m}^{-2} \mathrm{~d}^{-1}$ for the SE monsoon and $0.037 \mathrm{~g} \mathrm{C} \mathrm{m}^{-2} \mathrm{~d}^{-1}$ for the NW monsoon period. Gieskes et al. (1988) estimated the primary production for this area at $1.9 \mathrm{~g} \mathrm{C} \mathrm{m}^{-2} \mathrm{~d}^{-1}$ for the $\mathrm{SE}$ monsoon and $0.9 \mathrm{~g} \mathrm{C}$ $\mathrm{m}^{-2} \mathrm{~d}^{-1}$ for the NW monsoon. According to these figures the zooplankton would respire about 3 to $4 \%$ of the production in this area (Table 3).

For micronekton this relation is more difficult to establish as the ETS values vary largely between the various taxa and only a rough estimate can be given. The biomass of the mesopelagic fish and crustaceans, which formed the major part of the RMT8 catches in the Banda Sea area, was on average 1.2 and $2.48 \mathrm{~g}$ wet wt $\mathrm{m}^{-2}$ respectively in the SE monsoon and 0.75 and $0.99 \mathrm{~g}$ wet wt $\mathrm{m}^{-2}$ respectively in the NW monsoon (Schalk \& Witte unpubl.). Myctophids and gonostamatids were the most abundant mesopelagic fishes, with an assumed average ETS activity of $160 \mu \mathrm{g}$-at $\mathrm{O}$ ( $\mathrm{g}$ wet $w t)^{-1} h^{-1}$; for crustaceans an average ETS activity of 80 $\mu \mathrm{g}$-at $\mathrm{O}(\mathrm{g} \text { wet } \mathrm{wt})^{-1} \mathrm{~h}^{-1}$ is assumed (see Fig. 7). The estimated ETS activity for both groups is therefore 142 $\mu \mathrm{g}$-at $\mathrm{O} \mathrm{m}^{-2} \mathrm{~h}^{-1}$ during the SE monsoon and $74.4 \mu \mathrm{g}$-at $\mathrm{O} \mathrm{m}{ }^{-2} \mathrm{~h}^{-1}$ during the NW monsoon. As the ETS/R ratio tends to be higher for fish and larger crustaceans, a ratio of 4 is assumed to convert ETS values to respira- tory activity. With a respiratory quotient of 0.8 , the carbon requirement for the micronekton would be roughly $0.018 \mathrm{~g} \mathrm{C} \mathrm{m}^{-2} \mathrm{~d}^{-1}$ for the $\mathrm{SE}$ monsoon and $0.009 \mathrm{~g} \mathrm{C} \mathrm{m}^{-2} \mathrm{~d}^{-1}$ for the NW monsoon, or about $1 \%$ of the primary production in this area.

Acknowledgements. The author thanks Prof. Dr J. J. Zijlstra, Prof. Dr S. van der Spoel, and anonymous reviewers for critical reading and comments on the manuscript, and Mr J. Y. Witte for identifying the studied micronekton species. Mr B. J. Bouwmeester is thanked for kindly providing some of his ETS data on North Sea zooplankton. This study was supported by Grant W85-186 of the Netherlands Foundation for the Advancement of Tropical Research. Research was carried out as a part of the 'Snellius II' expedition organized by the Netherlands Council of Sea Research (NRZ) and the Indonesian Institute of Science (LIPI)

\section{LITERATURE CITED}

Ahmed, S. I., Kenner, R. A., King, F. D. (1976). Preservation of enzyme activity by low temperature freezing. Mar. Chem. 4: $133-139$

Alldredge, A. L. (1984). The quantitative significance of gelatinous zooplankton as pelagic consumers. In: Fasham, M. J. R. (ed.) Flows of energy and materials in marine ecosystems. Theory and practice. Plenum Press, New York, p. 407-433

Angel, M. V. (1986). Vertical migrations in the oceanic realm: possible causes and probable effects. In: Rankin, M. A. (ed.) Migration: mechanisms and adaptive significance. Contr. mar. Sci. 27 (Suppl.): 45-70

Anraku, M. (1964). Influence of the Cape Cod Canal on the hydrography and on the copepods in Burzards Bay and Cape Cod Bay, Massachusetts. I. Respiration and feeding. Limnol. Oceanogr. 9: 195-206

Baars, M. A., Zijlstra, J. J. (1988). Monsoon induced changes in the pelagic ecosystem of the Banda Sea: preliminary results of the Indonesian Dutch Snellius II expedition 1984/ 1985. Proc. WESTPAC symp. 1986, Townsville, Australia (in press)

Baker, A. de C., Clarke, M. R., Harris, M. J. (1973). The NIO combination net RMT $(1+8)$ and further developments of rectangular midwater trawls. J, mar. biol. Ass. U. K. 53: $167-184$

Båmstedt, U. (1979). Seasonal variation in respiratory rate and ETS activity of deep water zooplankton from the Swedish west coast. In: Naylor, E., Hartnoll, R. G. (eds.) Proceedings 13th European Marine Biology Symposium. Pergamon Press, Oxford, p. 267-274

Båmstedt, U. (1980). ETS activity as an estimator of respiratory rate of zooplankton populations. The significance of variations in an environmental factor. J. exp. mar. Biol. Ecol. 42: $267-283$

Beukema, J. J. (1974). Seasonal changes in biomass of the macrobenthos of a tidal flat area in the Dutch Wadden Sea. Neth. J. Sea Res. 8 (1): 94-107

Bigidaire, R. R., King, F. D., Biggs, D. C. (1982). Glutamate dehydrogenase and respiratory electron transport system activities in the Gulf of Mexico zooplankton. J. Plankton Res. 4 (4): 895-912

Biggs, D. C. (1977). Respiration and ammonium secretion by open ocean gelatinous zooplankton. Limnol. Oceanogr. 22 (1): $108-117$ 
Childress, J. J. (1969). The respiratory physiology of the oxygen minimum layer mysid Gnatthophausia ingens. Ph. D dissertation, Stanford University, Stanford

Childress, J. J. (1971). Respiratory rate and depth of occurrence of midwater animals. Limnol. Oceanogr. 16: 104-106

Childress, J. J. (1975). The respiratory rates of midwater crustaceans as a function of depth of occurrence and relation to the oxygen minimum layer off Southern California. Comp. Biochem. Physiol. 50A: 787-799

Christensen, J. P., Packard, T T. (1979). Respiratory electron transport activities in phytoplankton and bacteria: comparison of methods. Limnol. Oceanogr. 24 (3): 576-583

Christensen, J. P., Owens, T G., Devol, A. H., Packard, T. T (1980). Respiration and physiological state in marine bacteria. Mar. Biol. 55: 267-276

Conover, R. J. (1959). Regional and seasonal variation in respiratory rate of marine copepods. Limnol. Oceanogr. 4: $259-268$

Conover, R. J., Corner, E. D. S. (1968). Respiration and nitrogen excretion by some marine zooplankton in relation to their life cycles. J. mar. biol. Ass. U. K. 48: 49-75

Devol, A. H. (1981). Vertical distribution of zooplankton respiration in relation to the intense oxygen maximum zones in two British Columbia, Canada, fjords. J. Plankton Res. 3 (4): 593-602

Finlay, B. J., Span, Arja, Ochsenbein-Gattlen, C. (1983). Influence of physiological state in indices of respiration rate in protozoa. Comp. Biochem. Physiol. 74A (2): 211-219

Gaudy, R. (1973). Les variations saisonieres de la respiration chez quatre espèces de copépodes pelagiques de Golfe de Marseille. Neth. J. Sea Res. 7: 267-279

Gieskes, W. W. C, Kraay, G. W., Nontji, A., Setiapermana, D., Sutomo, A. (1988). Monsoonal differences in the level of primary productivity in the Band-Arafura region (Indonesia) and assessment of the carbon specific growth rate of the most important species group by $14 \mathrm{C}$ labeling of class-specific carotenoids. Neth. J. Sea Res. (in press)

Hirche, H.-J. (1984). Temperature and metabolism of plankton I. Respiration of antarctic zooplankton at different temperatures with a comparison of Antarctic and Nordic krill. Comp. Biochem. Physiol. 77a (2): 361-368

Huntley, M. Brooks, E. R. (1982). Effects of age and food availability on diel vertical migration of Calanus pacificus. Mar. Biol. 71 : 23-31

Ikeda, T. (1970). Relation between respiratory rate and body size in marine planktonic animals as a function of the temperature of habitat. Bull. Fac. Fish. Hokkaido Univ. 21: 91-112

Ikeda, T (1974). Nutritional ecology of marine zooplankton. Mem. Fac. Fish. Hokkaido Univ. 22: 1-97

Ikeda, T., Hing Fay (1981). The metabolic activity of zooplankton from the Antarctic Ocean. Aust. J. mar Freshwat. Res. 32: $921-930$

Ikeda, T., Skjoldal, H. R. (1980). The effect of laboratory conditions on the extrapolation of experimental measurements to the ecology of marine zooplankton 6 . Changes in physiological activities and biochemical components of Acetes sibogae australis and Acetes australis after capture. Mar Biol. 58 (4) : 285-294

Jannasch, H. W., Wirsen, C. O. (1973). Deep-sea microorganisms: in situ response to nutrient enrichment. Science 180 : $641-643$

Jannasch, H. W., Wirsen, C. O., Taylor, C. D. (1976). Undecompressed microbial populations from the deep-sea. Appl. environ. Microbiol. 32: 360-367

King, F. D., Packard, T. T (1975). Respiration and the activity of the respiration electron transport system in marine zooplankton. Limnol. Oceanogr. 20 (5): 849-854
Kenner, R. A., Ahmed, S. J. (1975a). Measurement of the electron transport activities in marine phytoplankton. Mar. Biol. 33: 119-127

Kenner, R. A., Ahmed, S. J. (1975b). Correlation between oxygen utilisation and electron transport activity in marine phytoplankton. Mar. Biol. 33: 129-133

Marshall, S. M. (1973). Respiration and feeding in copepods. Adv. mar. Biol. 11. 57-120

Marshall, S. M., Orr, A. P. (1956). On the biology of Calanus finmarchicus $X$. Seasonal changes in oxygen consumption. J. mar. biol. Ass. U. K. 37: 459-472

McLaren, I. A. (1963). Effect of temperature on growth of zooplankton and the adaptive value of vertical migration. J. Fish. Res. Bd Can. 20: 685-727

Mullin, M. M., Brooks, E. R. (1970). The effect of concentration of food on bodyweight, cumulative ingestion, and rate of growth of the marine copepod Calanus helgolandicus. Limnol. Oceanogr. 15: 748-755

Musayeva, E. I., Shushkina, E. A. (1978). Metabolic rates of planktonic animals at different temperatures. Oceanology 18 (3): $34.3-346$

Omori, M. (1970). Variations in length, weight, respiration rate and chemical composition of Calanus cristatus in relation to its food and feeding. In: Steele, J. H. (ed.) Marine food chains. Oliver and Boyd, Edinburgh, p. 113-126

Owens, T. G., King, F. D. (1975). The measurement of respiratory electron transport system activity in marine zooplankton. Mar. Biol. 30: 27-36

Packard, T. T. (1971). The measurement of respiratory electron transport system activity in marine phytoplankton. J. mar. Res. 29 (3): 235-244

Packard, T. T., Devol, A. H., King, F. D. (1975). The effect of temperature on the respiratory electron transport system in marine plankton. Deep Sea Res. 22: 237-249

Raymont, J. E. G. (1983). Plankton und productivity in the oceans, Vol. 2, Zooplankton. Pergamon Press, Oxford

Razouls, S. (1972). Influence des conditions expérimentales sur taux respiratoire des copepodes planctoniques. J. exp. mar. Biol. Ecol. 9: 145-153.

Roe, H. S. J. (1984). The diel migrations and distributions within a mesopelagic community in the north-east Atlantic. 2. Vertical migrations and feeding of mysids and decapod crustaceans. Progr. Oceanogr. 13: 269-318

Roe, H. S. J., Baker, A. de C., Carson, R. M., Wilde, R., Shale, D. M. (1980). Behaviour of the Institute of Oceanographic Science's rectangular midwater trawls: theoretical aspects and experimental observations. Mar. Biol. 56: 247-259

Schalk, P. H. (1987). Monsoon related changes in zooplankton biomass in the eastern Banda Sea and western Arafura Sea. Biol. Oceanogr. 5 (1): 1-12

Skjoldal, H. R., Båmstedt, U. (1977). Ecobiochemical studies on the deep water pelagic community of Korsfjorden, western Norway. Adenine nucleotides in zooplankton. Mar. Biol. 42: 197-211

Smith, K. L., Teal, J. M. (1973). Temperature and pressure effects on respiration of thecosomateous pteropods. Deep Sea Res. 20 (9): 853-858

Teal, J. M., Carey, F. G. (1967). Effects of pressure and temperature on the respiration of euphausiids. Deep Sea Res. 14: 725-733

Torres, J. J., Belman, B. W., Childress, J. J. (1979), Oxygen consumption of midwater fishes as a function of depth of occurrence. Deep Sea Res. 26A: 185-197

Vosjan, J. H., Nieuwland, G. (1987). Microbial biomass and respiratory activity in the surface waters of the east Banda Sea and northwest Arafura Sea (Indonesia) at the time of the southeast monsoon. Limnol. Oceanogr. 32 (3): 767-775 
Wiebe, P. H., Madin, L. P., Haury, L. R., Harbison, G. R., Philbin, L. M. (1979). Diel vertical migration by Salpa aspera and its potential for large-scale particulate organic matter transport to the deep-sea. Mar Biol. 53: 249-255

Wyrtki, K. (1957). The water exchange between the Pacific and Indian Oceans in relation to upwelling processes. Proc. 9th Pac. Sci. Congr 16: 61-66

Wyrtki, K. (1961). Physical oceanography of the southeast.
Asian waters. Naga Rep. 2. Scripps Inst. Oceanogr., La Tolla

Zijlstra, J. J., Baars, M. A., Tijssen, S. B., Wetsteijn, F. J., Witte, J., Ilahude, A. G., Hadikusuma (1988). Monsoon effect on hydrography of the upper waters $(<300 \mathrm{~m})$ of the eastern Banda Sea and northern Arafura Sea, with a special reference to vertical transport processes. Neth J. Sea Res. (in press)

This article was submitted to the editor; it was accepted for printing on February 11, 1988 